\title{
Amphiphilic Carbohydrate-Based Mesogens, 11 [1] Synthesis of Mesogenic 1-Alkylthio-1-deoxy-D-galactitols by Glycoside Reduction
}

\author{
Wilhelm V. Dahlhoffa,*, Karin Radkowski ${ }^{\mathrm{a}}$, Klaus Riehl ${ }^{\mathrm{b}}$, Peter Zugenmaier ${ }^{\mathrm{b}}$ \\ a Max-Planck-Institut für Kohlenforschung, Kaiser-Wilhelm-Platz 1, \\ D-45466 Mülheim an der Ruhr \\ b Institut für Physikalische Chemie der TU Clausthal, Arnold-Sommerfeld-Straße 4, \\ D-38678 Clausthal-Zellerfeld
}

Z. Naturforsch. 50b, 1079-1085 (1995); received November 30, 1994

Carbohydrates, Liquid Crystals (Smectic), Alkyl-1-thio- $\alpha / \beta$-D-galactopyranosides,

1-Alkylthio-1-deoxy-D-galactitols, Glycoside Reduction, X-Ray Diffraction (Small Angle)

Alkyl-1-thio- $\alpha / \beta$-D-galactopyranosides (hexyl-dodecyl, 1a-g) have been O-diethylborylated and then reduced with tetraethyldiboranes(6) in the presence of 9-methylsulfonyloxy9-borabicyclo[3.3.1]nonane (MSBBN) catalyst to give 1-alkylthio-1-deoxy-D-galactitols $\mathbf{3 a - g}$ after deprotection. 3 exhibit the smectic A liquid crystalline phase on melting.

Amphiphilic carbohydrate derivatives merit study for a number of reasons. They have, for example, proved useful for the solubilization and crystallization of membrane proteins [2] and they can also have interesting, as yet poorly understood biological functions: Racemic 1-O- $n$-pentyl-glycerol can permeate the blood-brain barrier [3], and the longer chain 3-O-alkyl-D-glucoses exhibit high inhibitory activity toward tumor cell growth [4]. 2-O- [5 a] and 3-O-alkyl-L-ascorbic acids [5 b] have been shown to be free radical quenchers which display interesting physiological activities. It is now well established that certain amphiphilic carbohydrates can form liquid crystals, and over the past decade these have attracted increasing attention [6].

Our interest in amphiphilic carbohydrates has been centred on the synthesis of chemically and thermally stable mesogens having $\mathrm{O}, \mathrm{S}$ or $\mathrm{CH}_{2}$ linkages between the polar alditol head group and the lipophilic alkyl chain [1]. After the first report on the synthesis of a homologous series of mesogenic 1-alkylthio-1-deoxy-D-mannitols [7a], the series of 3-alkylthio-1,2-propanediols [7b] and 1-alkylthio-1-deoxy-D-glucitols [7c] have also been described. Below we extend this list of thioether alditol amphiphiles by describing the prepa-

\footnotetext{
* Reprint requests to Dr. W. V. Dahlhoff.
}

ration of hexyl to dodecyl 1-alkylthio-1-deoxyD-galactitols.

\section{Results and Discussion}

It has been reported that, in general, 1,2-trans1-thioglycosides can be prepared by reaction of 1,2-trans per-O-acetates with thiols in chloroform in the presence of 4-5 equivalents of $\mathrm{F}_{3} \mathrm{~B}-\mathrm{OEt}_{2}$ at room temperature [8]. In the case of $1,2,3,4,6-$ penta-O-acetyl- $\beta$-D-glucopyranose a mixture containing about $70 \%$ of the alkyl-1-thio- $\alpha$-D-glucopyranosides together with $30 \%$ of the $\beta$-D-glucopyranosides was obtained [7 c, 9].

Because of this, it did not surprise us to find that the condensation of 1,2,3,4,6-penta-O-acetyl- $\beta$-Dgalactopyranoside with hexanethiol to dodecylthiol in the presence of $\mathrm{F}_{3} \mathrm{~B}-\mathrm{OEt}_{2}$ yielded product mixtures containing circa $65 \%$ alkyl-1-thio- $\alpha$-Dgalactopyranosides and $35 \%$ of the corresponding $\beta$-D-glycosides. As mentioned previously [7c] for the preparation of alkyl-1-thio- $\alpha, \beta$-D-glucopyranosides, the reported procedure can be improved in several ways: Firstly, the amount of $\mathrm{F}_{3} \mathrm{~B}-\mathrm{OEt}_{2}$ can be reduced to two equivalents, and secondly the reaction times can be shortened to about $30 \mathrm{~min}$ by carrying out the reaction in small volumes of refluxing chloroform.

Deacetylation to give the crude alkyl-1-thio$\alpha, \beta$-D-galactopyranosides $\mathbf{1} \mathbf{a}-\mathbf{g}$ was achieved by standard Zemplén saponification using methanolic 


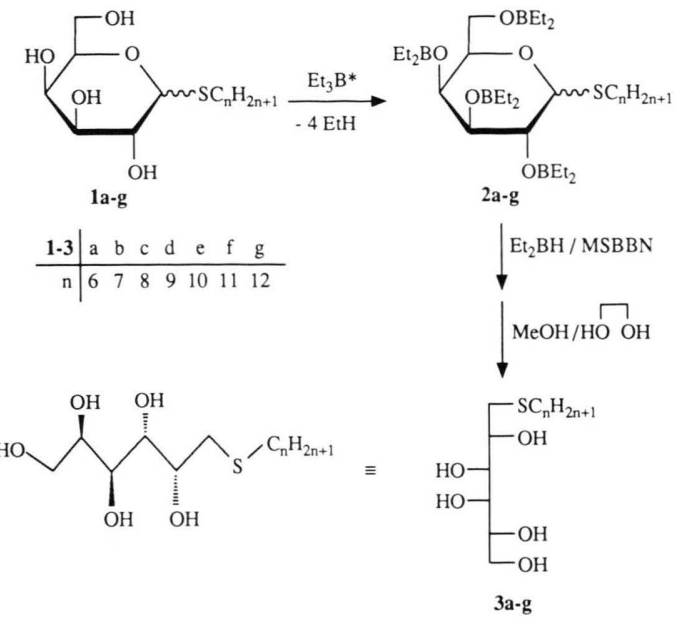

Scheme 1. Reaction scheme.

sodium methoxide. $1 \mathbf{a}-\mathbf{g}$ were then converted into alkyl-2,3,4,6-tetra-O-diethylboryl-1-thio- $\alpha, \beta$-D-galactopyranosides $\mathbf{2} \mathbf{a - g}$ on reaction with activated triethylborane in heptane.

The quantitative glycoside reductions of $\mathbf{2} \mathbf{a}-\mathbf{g}$ were realized by reacting them with tetraethyldiborane in the presence of 0.1 equivalent of MSBBN (9-BBN mesylate) at $120^{\circ} \mathrm{C}$ for $c a .7 \mathrm{~h}$. As the course of the reactions were not monitored, it is likely that shorter reaction times might suffice. The reaction mixtures were concentrated in vacuo and the residues deboronated to give pure 1-alkylthio-1-deoxy-D-galactitols $\mathbf{3 a - g}$ in yields of $65-83 \%$ (see Table II).

This approach to the preparation of 1-alkylthio1-deoxy-D-galactitols by regioselective hydroboration of the endocyclic acetal bond is an im- provement of the procedures reported previously [10].

The amphiphilic $\mathbf{3} \mathbf{a}-\mathbf{g}$ display unusual solubility behaviour. They are either insoluble in or dissolve and precipitate out quickly from the following solvents: water, methanol, ethanol, DMSO, pyridine, $\mathrm{Et}_{2} \mathrm{O}$, toluene, pentane and acetone. Usually the shorter chain members in a series of amphiphiles are more soluble in polar solvents whereas an increase in chain length is accompanied by increasing solubility in apolar solvents.

In order to characterize $\mathbf{3} \mathbf{a}-\mathbf{g}$ by NMR spectroscopy, samples were first converted to the pentaO-acetyl derivatives by reaction with acetic anhydride in pyridine. The D-galactitol moiety adopts a planar zigzag conformation as evidenced by the characteristic threo couplings $J_{2,3}=J_{4,5}=1.6 \mathrm{~Hz}$ and the typical erythro coupling von $J_{3,4}=10 \mathrm{~Hz}$.

The melting points of $\mathbf{3} \mathbf{a}-\mathbf{g}$ are fairly high and cover a very narrow range from 148 to $154^{\circ} \mathrm{C}$ ( cf. Table I and Fig. 1. The phase transition temperatures, as determined by polarizing microscopy, are in good agreement with the values found by differential scanning calorimetry (DSC). Of the amphiphiles $\mathbf{3 a - g}$, only 1-hexylthio-1-deoxy-Dgalactitol 3 a melts to form an isotropic melt. However, on cooling by $\sim 3^{\circ} \mathrm{C}$, mesophase formation occurs as indicated by the appearance of bâtonnets. All the higher homologues are enantiotropic mesogens which melt to give the smectic A mesophase. Polarizing microscopy allows the characteristic textures of this phase to be observed [12]. Typically, the bâtonnets which form at the clearing point on cooling the isotropic melt, coalesce to give the focal-conic texture. Large, essentially homeotropic, areas are also observed together with oily streaks.

\begin{tabular}{|c|c|c|c|c|c|c|c|}
\hline $\begin{array}{l}\text { Com- } \\
\text { pound }\end{array}$ & $n^{\mathrm{b}}$ & $\begin{array}{l}\text { Crystal-crystal } \\
\text { transition }\left[{ }^{\circ} \mathrm{C}\right]^{\mathrm{c}}\end{array}$ & $\begin{array}{l}\text { M.p. } \\
{\left[{ }^{\circ} \mathrm{C}\right]}\end{array}$ & $\begin{array}{l}\Delta \mathrm{H} \\
{\left[\mathrm{kJ} \mathrm{mol}^{-1}\right]}\end{array}$ & $\begin{array}{l}\text { C.p. } \\
{\left[{ }^{\circ} \mathrm{C}\right]}\end{array}$ & $\begin{array}{l}\Delta \mathrm{H} \\
{\left[\mathrm{kJ} \mathrm{mol}^{-1}\right]}\end{array}$ & $\begin{array}{l}\text { Stable } \\
\text { mesophase } \\
\text { range }\left[{ }^{\circ} \mathrm{C}\right]\end{array}$ \\
\hline $3 \mathbf{a}$ & 6 & $92.3(7.8)$ & 154.1 & 57.4 & $151.4^{\mathrm{d}}$ & $3.2^{\mathrm{d}}$ & $-^{\mathrm{e}}$ \\
\hline $\mathbf{3 b}$ & 7 & $83.5(4.8)$ & 152.1 & 55.4 & 167.4 & 2.6 & $\sim 15$ \\
\hline $3 c$ & 8 & $104.4(4.7)$ & 149.0 & 60.2 & 177.4 & 2.6 & $\sim 28$ \\
\hline $3 d$ & 9 & $108.7(2.4)$ & 152.0 & 59.6 & 186.1 & 2.4 & $\sim 34$ \\
\hline $3 e$ & 10 & $\begin{array}{c}56.6(0.9), \\
107.6(5.2)\end{array}$ & 148.0 & 57.5 & 185.5 & 2.7 & $\sim 38$ \\
\hline $3 f$ & 11 & $\begin{array}{r}52.4(1.1), \\
113.4(7.1)\end{array}$ & 148.9 & 57.9 & 192.5 & 1.8 & $\sim 44$ \\
\hline $3 g$ & 12 & $122.2(4.6)$ & 148.8 & 59.7 & 190 & 1.5 & $\sim 41$ \\
\hline
\end{tabular}

Table I. Transition temperatures and enthalpies of the phase transition of $\mathbf{3} \mathbf{a}-\mathbf{g}^{\mathrm{a}}$.

\footnotetext{
a Determined with a DuPont 1090 calorimeter. Heating rates $10{ }^{\circ} \mathrm{C} \mathrm{min}^{-1}$; ${ }^{\mathrm{b}}$ number of carbon atoms in the alkyl chain; ${ }^{c}$ enthalpies $\left(\mathrm{kJ} \mathrm{mol}^{-1}\right)$ in brackets; ${ }^{d}$ values found on cooling the isotropic melt; e monotropic mesophase.
} 
Table II. Yields, optical rotations, analytical and mass spectrometric data for the 1-alkylthio-1-deoxy-D-galactitols 3a-g.

\begin{tabular}{|c|c|c|c|c|c|c|c|c|c|}
\hline $\begin{array}{l}\text { Com- } \\
\text { pound }\end{array}$ & $\begin{array}{l}\text { Yield }^{\mathrm{a}} \\
{[\%]}\end{array}$ & $\begin{array}{l}\text { Formula } \\
\text { [mol. mass] }\end{array}$ & $\begin{array}{l}\text { Analys } \\
\text { C } \\
\text { calcd } \\
\text { (found) }\end{array}$ & $\begin{array}{l}\text { es }[\%] \\
\quad \mathrm{H} \\
\text { calcd } \\
\text { (found) }\end{array}$ & $\begin{array}{l}\mathrm{S} \\
\text { calcd } \\
\text { (found) }\end{array}$ & $\begin{array}{l}{[\alpha]_{\mathrm{D}}^{20^{\mathrm{b}}}} \\
\left(c, \mathrm{C} \mathrm{HCl}_{3}\right)\end{array}$ & $\begin{array}{l}\text { Four } \\
\mathrm{M}^{+}\end{array}$ & $\begin{array}{l}\mathrm{d} m / z \\
\text { Base } \\
\text { mass }\end{array}$ & $\begin{array}{l}\text { (\% rel. intensity) } \\
\text { Other characteristic masses }\end{array}$ \\
\hline $3 \mathbf{a}$ & 79 & $\begin{array}{l}\mathrm{C}_{12} \mathrm{H}_{26} \mathrm{O}_{5} \mathrm{~S} \\
{[282.4]}\end{array}$ & $\begin{array}{l}51.04 \\
(51.08)\end{array}$ & $\begin{array}{c}9.28 \\
(9.31)\end{array}$ & $\begin{array}{c}11.35 \\
(10.92)\end{array}$ & $\begin{array}{l}3.3 \\
(0.6)\end{array}$ & $<1$ & 43 & $\begin{array}{l}264(3), 246(4), 233(6), \\
215(24), 173(17), 147(30) \\
129(31), 61(74)\end{array}$ \\
\hline $3 \mathbf{b}$ & 83 & $\begin{array}{l}\mathrm{C}_{13} \mathrm{H}_{28} \mathrm{O}_{5} \mathrm{~S} \\
{[296.4]}\end{array}$ & $\begin{array}{c}52.68 \\
(51.89)\end{array}$ & $\begin{array}{c}9.52 \\
(9.73)\end{array}$ & $\begin{array}{c}10.82 \\
(10.74)\end{array}$ & $\begin{array}{c}3.7 \\
(0.6)\end{array}$ & $<1$ & 57 & $\begin{array}{l}278(3), 260(4), 247(8) \\
229(31), 187(21), 147(42) \\
129(42), 61(83)\end{array}$ \\
\hline $3 c$ & 75 & $\begin{array}{l}\mathrm{C}_{14} \mathrm{H}_{30} \mathrm{O}_{5} \mathrm{~S} \\
{[310.4]}\end{array}$ & $\begin{array}{c}54.17 \\
(53.65)\end{array}$ & $\begin{array}{c}9.74 \\
(9.66)\end{array}$ & $\begin{array}{l}10.33 \\
(10.47)\end{array}$ & $\begin{array}{c}4.3 \\
(0.6)\end{array}$ & - & 73 & $\begin{array}{l}292(5), 274(8), 243(50), \\
201(42), 159(77), 147(76), \\
129(75), 87(69)\end{array}$ \\
\hline $3 d$ & 65 & $\begin{array}{l}\mathrm{C}_{15} \mathrm{H}_{32} \mathrm{O}_{5} \mathrm{~S} \\
{[324.5]}\end{array}$ & $\begin{array}{c}55.52 \\
(55.70)\end{array}$ & $\begin{array}{c}9.94 \\
(9.90)\end{array}$ & $\begin{array}{c}9.88 \\
(10.48)\end{array}$ & $\begin{array}{c}4.1 \\
(0.5)\end{array}$ & - & 43 & $\begin{array}{l}306(4), 288(5), 257(39), \\
215(27), 173(61), 159(39), \\
147(71), 129(81)\end{array}$ \\
\hline $3 e$ & 72 & $\begin{array}{l}\mathrm{C}_{16} \mathrm{H}_{34} \mathrm{O}_{5} \mathrm{~S} \\
{[338.5]}\end{array}$ & $\begin{array}{c}56.77 \\
(56.70)\end{array}$ & $\begin{array}{c}10.12 \\
(10.11)\end{array}$ & $\begin{array}{c}9.47 \\
(9.56)\end{array}$ & $\begin{array}{l}3.5 \\
(0.7)\end{array}$ & - & 43 & $\begin{array}{l}320(3), 302(4), 271(35) \\
229(22), 187(48), 173(31) \\
147(64), 129(70)\end{array}$ \\
\hline $3 f$ & 65 & $\begin{array}{l}\mathrm{C}_{17} \mathrm{H}_{36} \mathrm{O}_{5} \mathrm{~S} \\
{[352.5]}\end{array}$ & $\begin{array}{c}57.92 \\
(57.42)\end{array}$ & $\begin{array}{l}10.29 \\
(10.58)\end{array}$ & $\begin{array}{c}9.09 \\
(9.17)\end{array}$ & $\begin{array}{c}3.2 \\
(0.6)\end{array}$ & - & 43 & $\begin{array}{l}334(3), 316(4), 285(29), \\
243(17), 201(41), 187(24), \\
147(59), 129(62)\end{array}$ \\
\hline $3 \mathbf{g}$ & 71 & $\begin{array}{l}\mathrm{C}_{18} \mathrm{H}_{38} \mathrm{O}_{5} \mathrm{~S} \\
{[366.5]}\end{array}$ & $\begin{array}{c}58.98 \\
(58.62)\end{array}$ & $\begin{array}{l}10.45 \\
(10.50)\end{array}$ & $\begin{array}{c}8.75 \\
(8.61)\end{array}$ & $\begin{array}{c}5.1 \\
(0.5)\end{array}$ & - & 43 & $\begin{array}{l}348(2), 330(3), 299(32) \\
257(26), 215(39), 201(25) \\
147(50), 129(53)\end{array}$ \\
\hline
\end{tabular}

a Yields of isolated pure products after reducing $\mathbf{2} \mathbf{a}-\mathbf{g}$ and subsequent deboronations $c f$. Experimental section; ${ }^{b}$ of the 2,3,4,5,6-penta-O-acetyl derivatives.

While the melting points of $\mathbf{3 a - e}$ lie $c a .50{ }^{\circ} \mathrm{C}$ above those of the 1-alkylthio-1-deoxy-D-glucitols $[7 \mathrm{c}]$, the clearing points for $\mathbf{3 a - d}$ only lie $\sim 20^{\circ} \mathrm{C}$ above those of the corresponding D-glucitol derivatives, and by the time the alkyl chain length has reached decyl, the clearing points only differ by $7{ }^{\circ} \mathrm{C}$. The lower melting points of the glucitol derivatives may be due to the 1,3-syn-interaction between the $\mathrm{C}^{2}$ and $\mathrm{C}^{4}$ hydroxy groups when the molecule is in a planar extended chain (zigzag) conformation. This destabilization can cause the sickle conformer to become thermodynamically favoured.

There are two essential requirements for the formation of a mesophase by single tailed carbohydrate-based amphiphiles. Firstly, the carbohydrate head group must have sufficient hydroxyl groups which are capable of participating in the build up of a hydrogen-bonded network, and secondly the alkyl chain must be sufficiently long (usually $\geq \mathrm{C}_{6}$ ) for effective chain interdigitation to occur. The initially proposed model [13] for the molecular arrangement in the smectic $A_{d}$ bilayers consists of a central region of hydrogen-bonded carbohydrate moieties with exterior hydrocarbon chains (Model I). A new model has recently been presented [14], in which the opposite arrangement is found, i.e. the interdigitated alkyl chains form the central region of the smectic bilayers and the hydrogen-bonded carbohydrate head groups are on the outside (Model II). This arrangement is essentially the same as that found in the fluid lamellar $\left(\mathrm{L}_{\alpha}\right)$ lyotropic phase [15], albeit without water being present. Furthermore, in the $\mathrm{L}_{\alpha}$ phase alkyl chain overlap does not occur.

The thickness of the layers in the crystal and of the smectic bilayers of 1-heptylthio- and nonylthio-1-deoxy-D-galactitols $\mathbf{3 b}$ and $\mathbf{3 d}$ have been determined by small-angle X-ray scattering measurements.

For $\mathbf{3 b}$ the d-spacing in the mesophase has been found to be $26.4 \AA$, which is $c a$. 1.5 times the molecular length if the molecule adopts a planar zigzag conformation. This value indicates that over- 
Table III. Characteristic ${ }^{1} \mathrm{H}$ and ${ }^{13} \mathrm{C}$ NMR data for $\mathbf{1}$ and penta-O-acetyl-3.

\begin{tabular}{|c|c|c|c|c|c|c|c|c|c|c|c|c|c|}
\hline Compound & C-1 & C-2 & C-3 & C-4 & C-5 & C-6 & $\begin{array}{l}1-\mathrm{H} \\
\left(J_{1,2}\right)\end{array}$ & $\begin{array}{l}2-\mathrm{H} \\
\left(J_{2,3}\right)\end{array}$ & $\begin{array}{l}3-\mathrm{H} \\
\left(J_{3.4}\right)\end{array}$ & $\begin{array}{l}4-\mathrm{H} \\
\left(J_{4,5}\right)\end{array}$ & $\begin{array}{l}5-\mathrm{H} \\
\left(J_{5.6 \mathrm{a}}\right)\end{array}$ & $\begin{array}{l}6 \mathrm{a}-\mathrm{H} \\
\left(J_{6 \mathrm{a}, 6 \mathrm{~b}}\right)\end{array}$ & $\begin{array}{l}6 \mathrm{~b}-\mathrm{H} \\
\left(J_{5.6 \mathrm{~b}}\right)\end{array}$ \\
\hline$\alpha-\mathbf{1}^{\mathrm{a}}$ & 85.4 & 67.9 & 70.5 & 68.6 & 71.5 & 60.5 & $\begin{array}{r}5.06 \\
(5.5)\end{array}$ & & & & & & \\
\hline$\beta-\mathbf{1}^{\mathrm{a}}$ & 85.7 & 69.9 & 74.8 & 68.3 & 79.0 & 60.6 & $\begin{array}{r}4.01 \\
(8.7)\end{array}$ & & & & & & \\
\hline 3-OAc ${ }^{b}$ & 33.9 & $68.4^{c}$ & $68.3^{c}$ & $67.7^{c}$ & $67.5^{c}$ & 62.0 & $\begin{array}{r}2.35 \\
(6.8)\end{array}$ & $\begin{array}{r}4.95 \\
(1.6)\end{array}$ & $\begin{array}{r}5.27 \\
(10.0)\end{array}$ & $\begin{array}{r}5.17 \\
(1.6)\end{array}$ & $\begin{array}{r}5.14 \\
(4.6)\end{array}$ & $\begin{array}{r}4.13 \\
(-11.6)\end{array}$ & $\begin{array}{c}3.68 \\
(7.5)\end{array}$ \\
\hline
\end{tabular}

a In $\mathrm{D}_{6}$-DMSO; ${ }^{\mathrm{b}}$ in $\mathrm{CDCl}_{3} ;{ }^{\mathrm{c}}$ assignments may be interchanged.

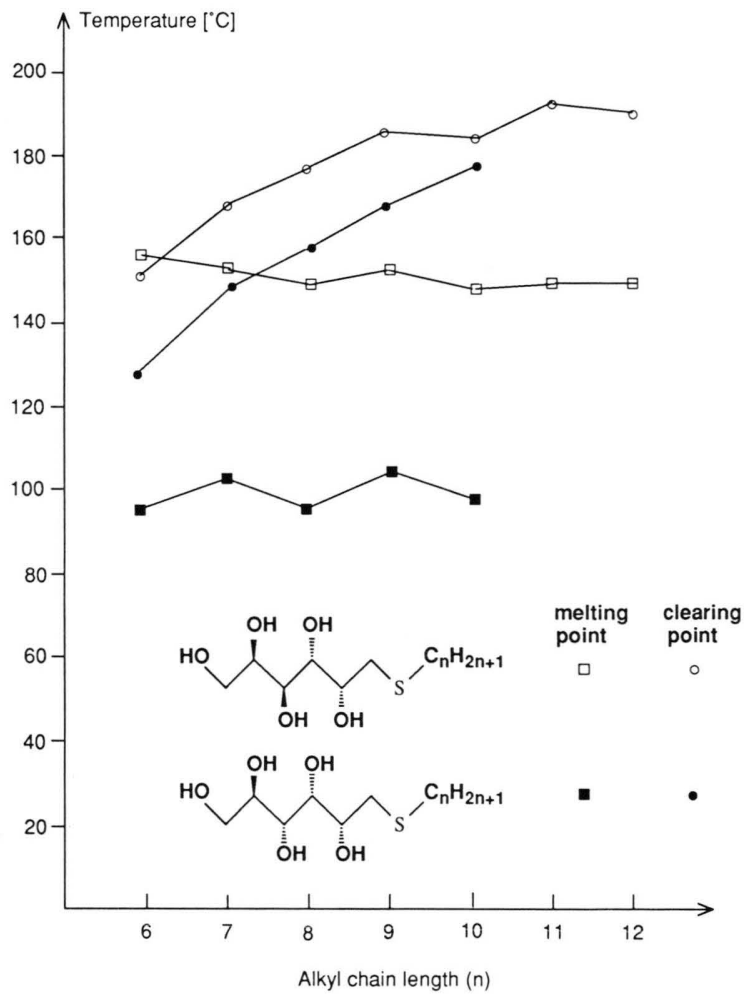

Fig. 1. Comparison of the phase-transition temperatures of 1-Alkylthio-1-deoxy-D-galactitols 3 and -D-glucitols.

lapping bilayers are present in the smectic phase. The same applies to $\mathbf{3 d}$ which has a layer spacing of $29.0 \AA$.

This increase in the bilayer spacing of $2.6 \AA$ in the smectic phase on going from $\mathbf{3 b}$ to $\mathbf{3} \mathbf{d}$ corresponds to the length of an extended ethylene group and points to interdigitation of the alkyl chains in the central region of the smectic bilayer. An increase of $c a .5 \AA$ would be expected for model I as alkyl chain extension would occur on
Table IV. Layer spacing for $\mathbf{3} \mathbf{b}$ and $\mathbf{3 d}$ in the crystalline and in the liquid-crystalline phase.

\begin{tabular}{lccc}
\hline \multirow{2}{*}{ Mesogen } & $n$ & \multicolumn{2}{l}{ Layer spacing, $\mathrm{d}(\AA)$} \\
& $n$ & Crystal & Mesophase \\
\hline 3b & 7 & 35.2 & 26.4 \\
$\mathbf{3 d}$ & 9 & 39.8 & 29.0 \\
\hline$\Delta \mathrm{d}^{\text {a }}$ & & 4.6 & 2.6 \\
\hline
\end{tabular}

a Difference in bilayer spacing between homologues $\mathbf{3 b}$ and $\mathbf{3 d}$.

both sides of the central bilayer region [14]. In the crystalline state, the layer spacing of $\mathbf{3} \mathbf{b}$ and $\mathbf{3 d}$ is 35.2 and $39.8 \AA$, respectively. These values correspond to approximately twice the length of the respective molecules. The increase in the layer spacing in the crystal of $4.6 \AA$ on going from $\mathbf{3 b}$ to $\mathbf{3 d}$ suggests that a model I type arrangement might exist. In the usual model I arrangement the individual sugar molecules overlap with the alkyl chains alternately pointing to the left and right of the central region.

A variety of other factors in favour of model II has also been accumulated [14]. For example, the fluid lamellar phase of Aerosol OT (sodium bis2-ethylhexyl sulfosuccinate) in water and the smectic A phase of decyl $\beta$-D-glucopyranoside were found to be fully miscible [16]. Investigations with dodecyl maltoside and water showed that up to $42 \mathrm{wt} . \%$ of water is incorporated into the layers before the hexagonal lyotropic phase is formed [17]. Interesting work by H. A. van Doren et al. [14] showed that when water is added to crystals of heptyl-1-thio- $\alpha$-D-glucopyranoside at room temperature, neither dissolution nor water penetration into the crystals is observed. On heating the sample dissolution occurs, without lyotropic mesophase formation. In contrast to this, when 

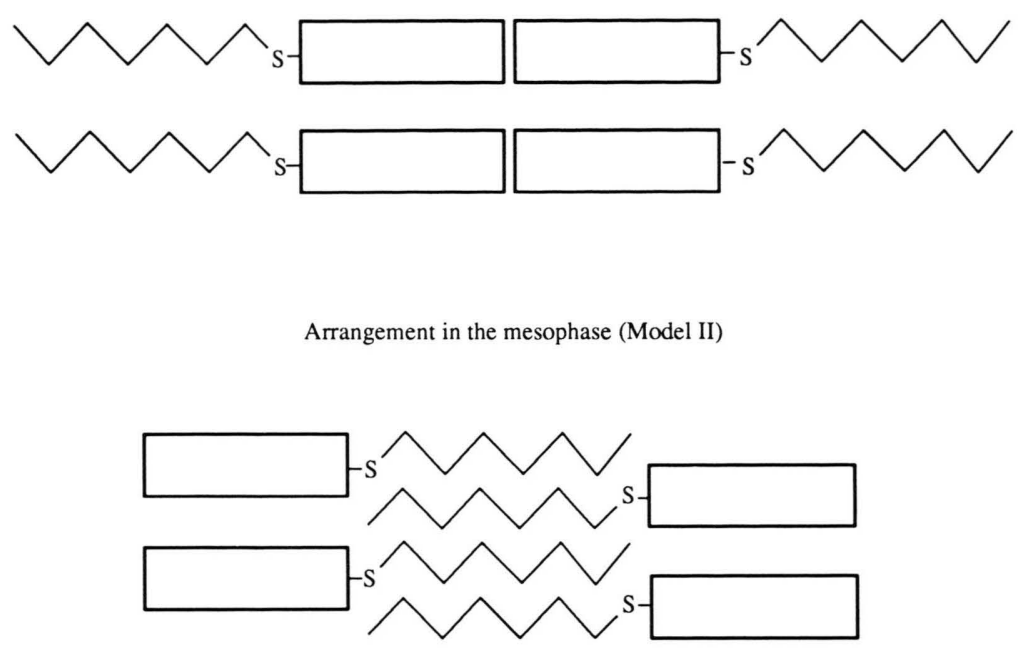

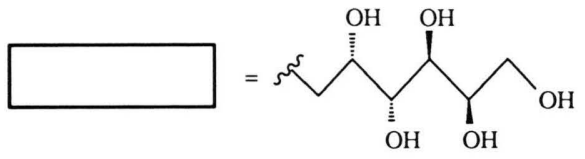

water is added to the supercooled smectic $A_{d}$ phase of the same amphiphile, penetration occurs readily at room temperature giving rise to cubic and hexagonal lyophases. The ease of water penetration is readily understood if one considers the carbohydrate head groups to be on the outside of the smectic bimolecular layer. The water insolubility of the smectogens presented here prevented similar experiments from being carried out.

\section{Experimental}

All experiments were carried out in dry deoxygenated solvents under an atmosphere of argon. - MS: Finnigan MAT CH5. $-{ }^{1} \mathrm{H}$ and ${ }^{13} \mathrm{C}$ NMR: Bruker AC 200. - DSC: DuPont 1090 calorimeter. - Optical rotations: Perkin-Elmer 241. $\mathrm{C}, \mathrm{H}, \mathrm{S}$ analyses were performed by Dornis and Kolbe, Mülheim an der Ruhr.

\section{Starting compounds}

Penta-O-acetyl- $\beta$-D-galactopyranoside was prepared from D-galactose with acetic anhydride in the presence of sodium acetate [18]. The 1-alkane-
Fig. 2. Schematic drawings of the possible molecular arrangements of the bilayers in the crystalline state and in the mesophase, depicted for $3 \mathbf{b}$. thiols and $\mathrm{F}_{3} \mathrm{~B}-\mathrm{OEt}_{2}$ (Aldrich) were vacuum-distilled prior to use. Triethylborane [19], ethyldiboranes(6) [20] and MSBBN [21] were prepared according to the references cited. Triethylborane containing $1 \mathrm{~mol} \%$ of diethylborylpivalate (socalled "activated triethylborane") was used for the O-diethylborylations [22].

\section{General procedures}

\section{Alkyl-1-thio- $\alpha, \beta$-D-galactopyranosides 1a-g:}

The thiol $(8.5 \mathrm{mmol})$ was added to the penta-Oacetyl- $\beta$-D-galactopyranoside $(7.7 \mathrm{mmol})$ in chloroform $(5 \mathrm{ml})$ and then $\mathrm{F}_{3} \mathrm{~B}-\mathrm{OEt}_{2}(15 \mathrm{mmol})$ was added to the stirred solution. The mixture was heated under reflux for $30 \mathrm{~min}$ and after cooling to ca. $20^{\circ} \mathrm{C}$ a saturated sodium bicarbonate solution $(35 \mathrm{ml})$ was carefully added in portions to destroy the catalyst. The mixture was transferred to a separating funnel and the flask washed with water $(\sim 5 \mathrm{ml})$. The combined aqueous phase was washed twice with diethyl ether $(20 \mathrm{ml})$ and the chloroform/ether extract was shaken with water $(20 \mathrm{ml})$ before drying over sodium sulfate. Finally the 
solvents were removed in vacuo to give brown, viscous acetylated glycosides in quantitative yields.

The deacetylations were achieved by adding methanol $(10 \mathrm{ml})$ and sodium methoxide (spatula tip) and stirring at r.t. until TLC (eluent: diethyl ether/hexane $1: 1$ ) showed no more starting material. 1a-g were obtained in quantitative yield on removing the solvent. They were converted to $2 \mathbf{a}-\mathbf{g}$ without purification. The anomeric mixtures contained $\sim 65 \%$ of the $\alpha$-D-glycoside and $\sim 35 \%$ of the $\beta$-D-anomer.

Alkyl-2,3,4,6-tetra-O-diethylboryl-1-thio- $\alpha, \beta$ - $D$ galactopyranosides 2a-g: Activated triethylborane $(5 \mathrm{ml})$ was added dropwise to a stirred suspension of $\mathbf{1} \mathbf{a}-\mathbf{g}(\mathrm{ca} .7 \mathrm{mmol})$ in heptane $(15 \mathrm{ml})$ at $60-70{ }^{\circ} \mathrm{C}$ (bath temperature) so that ethane $(28 \mathrm{mmol})$ was evolved at a steady and rapid rate. Insoluble material was filtered off and the solu- tions were then concentrated in vacuo $\left(0.1-10^{-3}\right.$ Torr) to leave $\mathbf{2} \mathbf{a}-\mathbf{g}$ as orange-coloured residues in $c$ a. $90 \%$ yield.

1-Alkylthio-1-deoxy-D-galactitols 3a-g: Ethyldiboranes(6) with hydride contents of $10-15 \%$ o $\mathrm{H}^{-}$ (about $10 \mathrm{mmol}$ ) and MSBBN (about $0.6 \mathrm{mmol}$ ) were added to 2 (about $6 \mathrm{mmol}$ ), and the stirred mixture was heated under reflux (bath temperature $c a .120^{\circ} \mathrm{C}$ ) for $7 \mathrm{~h}$. The mixture was concentrated in vacuo $\left(10^{-3}\right.$ Torr $)$ and the residue treated with methanol $(10 \mathrm{ml})$ and pyridine $(0.5 \mathrm{ml})$ and concentrated in vacuo. 1,2-Ethanediol (five times $3 \mathrm{ml}$ portions) was added and distilled off in vacuo $\left(10^{-3}\right.$ Torr $)$ before adding ethanol $(20 \mathrm{ml})$ and concentrating the mixture in vacuo. Pure $\mathbf{3 a - g}$ were isolated as white solids in yields of $65-83 \%$ ( $c f$. Table II) by addition of diethyl ether $(20 \mathrm{ml})$, filtration and drying.
[1] Part 10: see W. V. Dahlhoff, K. Radkowski, P. Zugenmaier, I. Dierking, Z. Naturforsch. 50b, 405-410 (1995), and references cited herein.

[2] a) J. Deisenhofer, H. Michel, Angew. Chem. 101, 872 (1989); Angew. Chem., Int. Ed. Engl. 28, 829 (1989);

b) M. Ahlers, W. Müller, A. Reichert, H. Ringsdorf, J. Venzmer, Angew. Chem. 102, 1310 (1990); Angew. Chem., Int. Ed. Engl. 29, 1269 (1990).

[3] H. Eibl, Angew. Chem. 96, 247 (1984); Angew. Chem., Int. Ed. Engl. 23, 257 (1984).

[4] T. Ikekawa, K. Irinoda, K. Saze, T. Katori, H. Matsuda, M. Ohkawa, M. Kosik, Chem. Pharm. Bull. 35, 2894 (1987).

[5] a) K. Kato, S. Terao, N. Shimamoto, M. Hirata, J. Med. Chem. 31, 793 (1988);

b) Y. Nihru, S. Sogawa, A. Izumi, A. Sasamori, T. Sudo, T. Miki, H. Matsumoto, T. Satoh, J. Med. Chem. 35, 1618 (1992).

[6] a) G. A. Jeffrey, L. M. Wingert, Liq. Cryst. 12, 179 (1992);

b) H. Ringsdorf, B. Schlarb, J. Venzmer, Angew. Chem. 100, 117 (1988); Angew. Chem., Int. Ed. Engl. 27, 113 (1988);

c) P. Köll, M. Oelting, Tetrahedron Lett. 27, 2837 (1986).
[7] a) W. V. Dahlhoff, Abstr. XII, Intern. Carbohydr. Symp., p. 26, Cornell University, Ithaca, N.Y. (1986); b) H. A. van Doren, R. van der Creest, R. M. Kellogg, H. Wynberg, Recl. Trav. Chim. Pays-Bas 109, 197 (1990);

c) W. V. Dahlhoff, Liebigs Ann. Chem. 1990, 1025.

[8] R. J. Ferrier, R. H. Furneaux, Methods Carbohydr. Chem. 8, 251 (1980).

[9] H. A. van Doren, R. van der Geest, R. M. Kellogg, H. Wynberg, Carbohydr. Res. 194, 71 (1989).

[10] An alternative synthetic route to 1-alkylthio-1deoxy-alditols involved reductive desulphurization of aldose dialkyl dithioacetals with Raney nickel [11 a]. Complete desulphurizations yielding 1-deoxy-alditols can however also occur using this method [11 b]. 1-Alkylthio-1-bromo-1-deoxy-aldose aldehydrols, which can be prepared by reacting aldose dialkyl dithio-acetal acetates with bromine, are reduced by $\mathrm{LiAlH}_{4}$ yielding 1-alkylthio-1-deoxyalditols [11 c].

[11] a) J. K. N. Jones, K. S. Mitchell, Canad. J. Chem. 36, 206 (1958);

b) B. Lindberg, L. Nordén. Acta Chem. Scand. 15, 958 (1961);

c) H. Zinner, R. Kleeschätzky, P. Neels, Chem. Ber. 98, 1492 (1965). 
[12] a) G. W. Hill, J. W. Goodby, Smectic Liquid Crystals, Leonard Hill, Glasgow, London (1984);

b) D. Demus, L. Richter, Textures of Liquid Crystals, Verlag Chemie, Weinheim (1978);

c) N. H. Hartshorne, A. Stuart, Crystals and the Polarizing Microscope, Edward Arnold Ltd., London (1970).

[13] a) G. A. Jeffrey, Acc. Chem. Res. 19, 168 (1986);

b) J. W. Goodby, Mol. Cryst. Liq. Cryst. 110, 205 (1984);

c) B. Pfannemüller, W. Welte, E. Chin, J. W. Goodby, Liq. Cryst. 1, 357 (1986);

d) J. W. Goodby, M. A. Marcus, E. Chin, P. L. Finn, B. Pfannemüller, Liq. Cryst. 3, 1569 (1988).

[14] a) G. A. Jeffrey, Mol. Cryst. Liq. Cryst. 185, 209 (1990);

b) H. A. van Doren, L. M. Wingert, Mol. Cryst. Liq. Cryst. 198, 381 (1991); c) W. V. Dahlhoff, Liebigs Ann. Chem. 1991, 463.

[15] H. Kelker, R. Hatz, Handbook of Liquid Crystals, Verlag Chemie, Weinheim (1980).

[16] M. A. Marcus, P. L. Finn, Mol. Cryst. Liq. Cryst. Lett. 2, 159 (1985).

[17] M. A. Marcus, P. L. Finn, Liq. Cryst. 3, 381 (1988).

[18] M. L. Wolfrom, A. Thompson, in R. L. Whistler, M. L. Wolfrom (eds): Methods in Carbohydrate Chemistry, Vol. II. p. 212, Academic Press, New York, London (1963).

[19] R. Köster, P. Binger, W. V. Dahlhoff, Synth. Inorg. Metal-Org. Chem. 3, 359 (1973).

[20] R. Köster, P. Binger, Inorg. Synth. 15, 141 (1974).

[21] R. Köster, W. V. Dahlhoff, W. Schüßler, Organomet. Synth. 4, 450 (1988).

[22] R. Köster, K.-L. Amen, W. V. Dahlhoff, Liebigs Ann. Chem. 1975, 752. 